\title{
Causes, consequences, and treatment of osteoporosis in men
}

\author{
This article was published in the following Dove Press journal: \\ Drug Design, Development and Therapy \\ 2I August 2013 \\ Number of times this article has been viewed
}

\author{
Jameela Banu \\ Coordinated Program in Dietetics, \\ College of Health Sciences and \\ Human Services and Department \\ of Biology, College of Science and \\ Mathematics, University of Texas-Pan \\ American, Edinburg, TX, USA
}

\begin{abstract}
Men undergo gradual bone loss with aging, resulting in fragile bones. It is estimated that one in five men will suffer an osteoporotic fracture during their lifetime. The prognosis for men after a hip fracture is very grim. A major cause is reduction of free testosterone. Many other factors result in secondary osteoporosis, including treatment for other diseases such as cancer and diabetes. Patients should be screened not only for bone density but also assessed for their nutritional status, physical activity, and drug intake. Therapy should be chosen based on the type of osteoporosis. Available therapies include testosterone replacement, bisphosphonates, and nutritional supplementation with calcium, vitamin D, fatty acids, and isoflavones, as well as certain specific antibodies, like denosumab and odanacatib, and inhibitors of certain proteins. Keywords: risk factors, hormones, bisphosphonates, nutritional supplements, antibodies, protein inhibitors, male osteoporosis
\end{abstract}

\section{Introduction}

Aging is associated with gradual bone loss in men, leading to fragile bones and increased fracture risk. Since bone loss in males was recognized as a serious medical condition a couple of decades ago, studies have focused on several aspects of the disease, including assessment, diagnosis, prevention, and treatment options. It is established that aging men lose bone mineral density (BMD) at a rate of $1 \%$ per year, ${ }^{1}$ and that one in five men will suffer an osteoporotic fracture during their lifetime., It is also believed that the incidence of osteoporosis-related fracture is similar to that of myocardial infarction and exceeds that of lung and prostate carcinoma combined. ${ }^{4}$ The disturbing fact is that when men have fractures, their chances of survival are considerably decreased. Moreover, awareness about osteoporosis in males is lacking in certain societies. ${ }^{5-7}$

Although it is recognized that osteoporosis in men is an important medical condition and will remain important as longevity increases around the globe, there are very poor tools for managing male osteoporosis. ${ }^{8,9}$ The diagnostic standards are dependent on the scales for women or young men, but there is a 10 -year difference in age before men show signs of an age-related decrease in bone mass. ${ }^{10}$ Moreover, many elderly men treated for fractures are not put on any medication regimen to treat osteoporosis. ${ }^{11}$ It is recommended that men should be evaluated for their bone status after 50 years of age, ${ }^{12}$ and the clinical practice guidelines recommend screening in men over 70 years. ${ }^{11,13}$

Patients older than 80 years are currently excluded, but the changes in physiology at this age usually put them at a different level of risk. ${ }^{14}$ Although screening patients 
for BMD is the best measure to know the status of bone, it is very important to collect information about the probable reasons for bone loss, because $75 \%$ of patients have been found to have secondary osteoporosis. ${ }^{15}$ There may be ethnicity-related differences among men as well. Roughly $7 \%$ of white men and $3 \%$ of black men have osteoporosis, with an additional $35 \%$ of white men and $19 \%$ of black men having low bone mass. This requires formulation of treatment and management strategies specific to ethnic groups. ${ }^{16}$ In addition to this, men with a combination of low bone mass and low muscle mass are at higher risk of losing bone. In this review, available data on the causes, consequences, and treatment options are discussed.

\section{Causes and consequences}

Several factors are believed to cause age-related bone loss in men, including decreased levels of sex hormones and insulin-like growth factor-1, drug side effects, and nutrition lacking minerals. Moreover, secondary osteoporosis may be due to several acquired habits and inherited conditions (Figure 1).

\section{Decrease in hormones}

With age, there is certainly a decrease in hormone levels. Androgens may play an important role in the regulation of bone formation in men. ${ }^{17}$ Total testosterone levels decrease at a rate of $0.8 \%$ per year, of which free and bound testosterone levels decrease at $2 \%$ per year (cross-sectional studies) and between $1.6 \%$ per year and $2 \%-3 \%$ per year (longitudinal studies). ${ }^{18}$ On the other hand, levels of sex hormone binding globulin (SHBG) increase with age. ${ }^{19-23}$ This protein binds to testosterone and decreases free or bioavailable testosterone. ${ }^{19,21,24-26}$ Men are also affected by changes in estrogen due to aging, because testosterone is the precursor to estrogen and it is well established that estrogen plays a greater role in increasing bone resorption. ${ }^{25}$ Therefore, in men, both hormones are important to maintain bone and are inversely related to fracture risk in older men contributed by decreased BMD. ${ }^{27,28}$ The action of androgen on bones in males may be explained by activation of the androgen receptor or the estrogen receptor ( $\alpha$ and $\beta$ ). ${ }^{28}$ Therefore, low serum estrogen and testosterone with high SHBG increases the risk of osteoporotic vertebral, nonvertebral, and hip fractures. ${ }^{28,29}$

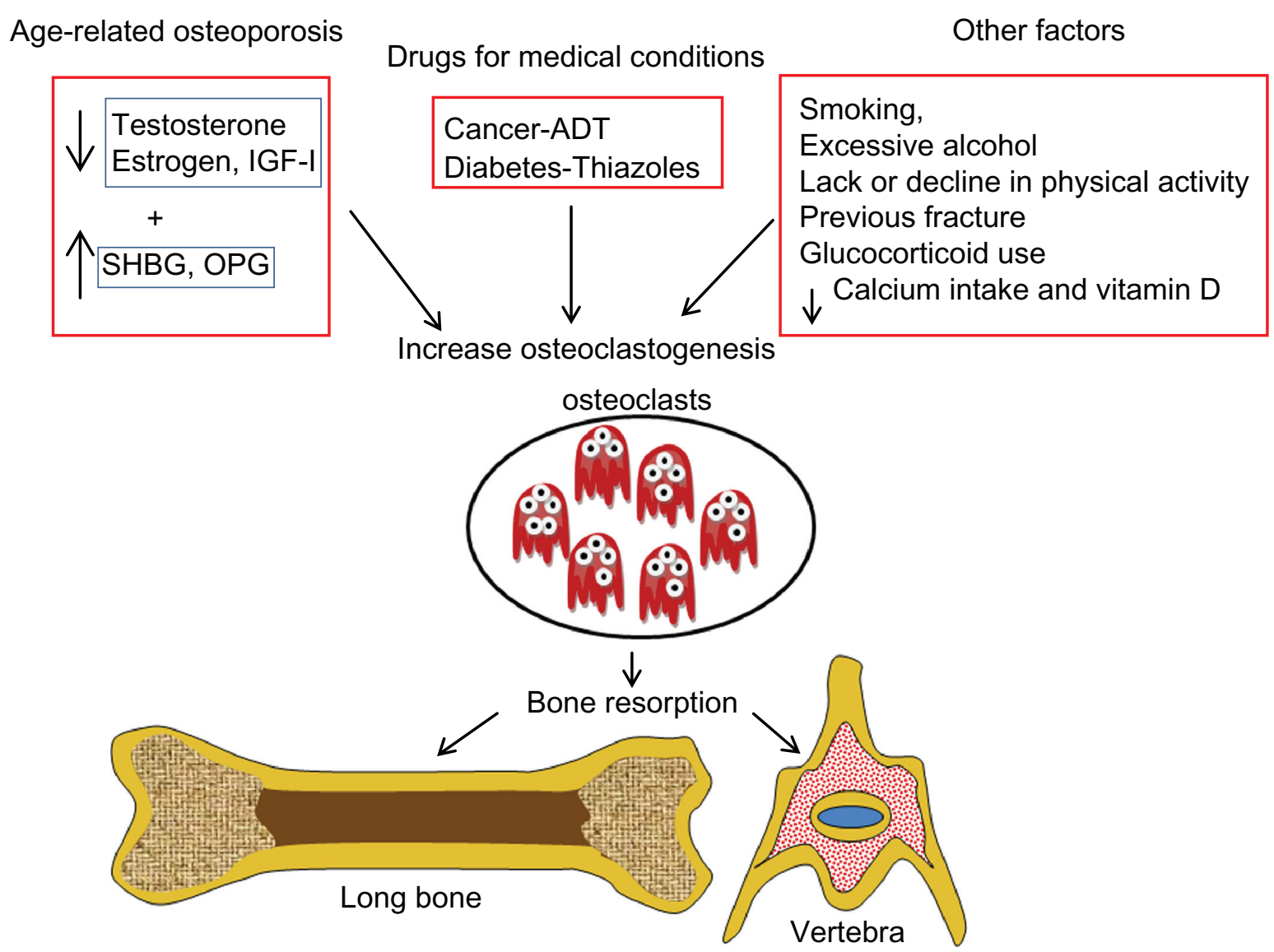

Figure I Factors that cause bone loss in men.

Abbreviations: IGF-I, insulin-like growth factor-I; SHBG, sex hormone binding globulin; OPG, osteoprotegerin; ADT, androgen deprivation therapy; $\uparrow$, increase; $\downarrow$, decrease. 
Apart from alterations in sex hormones, decreased insulin-like growth factor-1 levels are found in men with vertebral fractures. ${ }^{30}$ In addition, men with a low body mass index and a small body frame have decreased estrogen levels, and the offspring of these men also have low BMD. ${ }^{31}$

Bone turnover and bone maintenance is a balance between proteins like osteoprotegerin and receptor activated nuclear factor kappa B ligand (RANKL). Osteoprotegerin levels in serum have been shown to increase with age, ${ }^{32}$ which in turn may increase bone loss.

\section{Side effects of drugs}

Patients with prostate cancer undergoing androgen deprivation and cyclophosphamide therapy have an increased fracture risk. ${ }^{33-36} \mathrm{BMD}$ measurements in men with prostate cancer and under an androgen deprivation regimen show $6.5 \%-17.3 \%$ bone loss. Moreover, this effect is site-specific and is also dependent on duration of treatment. ${ }^{37-39}$

Antidiabetic drugs like thiazides also cause bone loss. ${ }^{40}$ Many studies in humans as well as in animals have shown that bone loss is accelerated by thiazoles. ${ }^{41-43}$ Rosiglitazone decreases bone quality by increasing porosity. ${ }^{40}$ In women and men, decreased bone mass in long bones, but not in the vertebrae, has been attributed to thiazides. ${ }^{44,45}$ There are a few studies that explain the mechanism by which these antidiabetic drugs cause bone loss. In males, glitazones reduce the biosynthesis of androgens, increase their binding to SHBG, and attenuate androgen receptor activation, thus reducing the physiologic actions of testosterone, causing relative and absolute androgen deficiency. ${ }^{46}$ In addition to this, activation of peroxisome proliferator activated receptor gamma initiates an imbalance in the bone resorption and bone formation process, resulting in high bone loss. ${ }^{47}$ Moreover, rosiglitazone induces apoptosis of osteoblasts which reduces bone formation. ${ }^{48}$

\section{Changes in bone turnover markers}

Bone turnover is assessed by measuring biomarkers such as cross linking C-terminal telopeptide of type I collagen and procollagen type $1 \mathrm{~N}$-terminal propeptide. Cross linking C-terminal telopeptide of type I collagen, in addition to being a bone resorption marker, is also used to assess adherence with bisphosphonates, while procollagen type $1 \mathrm{~N}$-terminal propeptide is a measure of bone formation. Higher bone turnover is not always related to decreased BMD in men. ${ }^{49}$ However, in the Dubbo study, only cross linking C-terminal telopeptide of type I collagen could predict fractures. ${ }^{50}$ Increased bone turnover reduces bone strength because faster bone loss increases bone formation. This sudden increase in bone formation impairs bone connectivity because a higher fraction of protein matrix undergoes partial post transcriptional modification, resulting in a malformed matrix. It is commonly observed that bone turnover markers are increased in institutionalized patients ${ }^{51}$ to a greater extent than in community-dwelling individuals. In older men, increased bone turnover markers are associated with lower areal BMD. ${ }^{49}$

\section{Secondary osteoporosis}

Most men who sustain fractures do so because of multiple other factors, including age, smoking, alcohol consumption, low weight, physical/functional limitations, previous fracture, weight loss, prolonged corticosteroid use, androgen deprivation therapy, dietary calcium intake, chronic lung disease, and prostate cancer. Accumulation of kidney stones is negatively correlated with BMD. ${ }^{52-54}$ Recent research shows that low levels of free $25(\mathrm{OH})$ vitamin D result in bone loss. ${ }^{55}$ The major mineral lost in bone loss is calcium, and calcium absorption is influenced by vitamin $\mathrm{D}$. Therefore, individuals who consume calcium in low amounts and who are diagnosed with vitamin D deficiency also have an increased fracture risk. $^{56-58}$

Osteoporosis affects men over 70 years of age. When BMD in both the trabecular and cortical bones is reduced, there is an increased risk of fractures of the hip and vertebrae, which are often fatal in men. Some patients have hypogonadism due to testicular failure or pituitary disorders, leading to bone loss. ${ }^{59}$ Medications for other medical conditions, including those for cancer, diabetes, and seizures, also cause osteoporosis. ${ }^{60}$ Apart from these, drugs that raise serum prolactin levels and chronic opioid use for pain control are also implicated in bone loss. Men who have fractures of the distal forearm and those who have symptomatic vertebral and hip fractures show lower BMD as well. ${ }^{61}$

Nevertheless, men have the advantage of accruing a higher peak bone mass $(8 \%-10 \%)$ compared with women. ${ }^{62,63}$ In addition, microarchitectural changes in the radius have been found to include higher trabecular thickness and bone volume/ total volume in men compared with women. ${ }^{64,65}$ In the tibia, significantly higher bone volume/total volume, trabecular number, and cortical thickness ${ }^{65}$ were reported. Although trabecular thickness was also increased, this was not statistically significant. However, these data are from younger individuals aged 19 years and 20-29 years. Longitudinal studies in older men showed an age-related decrease in trabecular thickness of the radius. However, there was decreased trabecular thickness, 
number, and separation in the distal tibia ${ }^{66}$ Cortical porosity is increased with age in men. ${ }^{67}$ Moreover, men undergo periosteal bone accretion compensating the endosteal bone loss and maintaining strength for almost a decade after women show bone fragility. ${ }^{66-70}$ However, men do lose bone gradually and are susceptible to fractures after the sixth decade of life.

The action of androgen on male bone may be explained by activation of the androgen receptor or estrogen receptor $\left(\alpha\right.$ and $\beta$ ). ${ }^{28}$ Serum estrogen and testosterone are inversely related to fracture risk in older men, while SHBG shows a positive relationship; low serum estrogen and testosterone levels coupled with high SHBG predict clinical vertebral and nonvertebral osteoporosis and hip fractures. ${ }^{17}$ SHBG has been reported to increase with age and is associated with bone loss. ${ }^{29}$

Orchidectomized rodents have been shown to have an increase in bone resorption markers and periosteal bone formation, and decreased bone strength, implicating the role of decreased testosterone. ${ }^{71}$ Because androgens play an important role in regulation of bone formation in males, their receptors, ie, the androgen receptor and estrogen receptor, should be activated for maintenance of bone in male mice. Estrogen receptor- $\alpha$ and the androgen receptor were found to increase cortical radial bone growth and mediate protection of cancellous bone in males. ${ }^{71}$ Moreover, androgen receptor activation is solely responsible for the development and maintenance of trabecular bone in males, and the androgen receptor and estrogen receptor- $\alpha$ are responsible for cortical bone mass and muscle mass. ${ }^{72,73}$ It is reported that estrogen receptor- $\alpha$ may act indirectly via the growth hormone-insulin-like growth factor- 1 axis. $^{74}$ Therefore, there is ample evidence that an age-related reduction of hormone secretion, especially sex hormones, affects bone maintenance in men.

Osteoporosis in men is a gradual disease that progresses with age. ${ }^{14}$ In the US, two million men are diagnosed with osteoporosis and another 12 million have low bone mass and are at the risk of developing the disease. ${ }^{75}$ The outcome for male patients after hip fracture (30\% of hip fractures occur in men) is grim. One third (32\%) die within the first year of hip fracture. ${ }^{76-78}$ Only $21 \%$ are able to live independently in the community a year after the fracture, with $26 \%$ receiving home care and 53\% living in an institution for the rest of their lives. ${ }^{79}$ Unfortunately, men with osteoporosis have higher mortality rates than women, and the fracture burden also increases the problems of osteoporosis in men. In one study, men with subsequent fractures were found to have an increased mortality rate and more men were immobilized at 120 days after their fracture. ${ }^{11}$

\section{Treatment options}

Available treatment options for men with osteoporosis are those that were developed for and are currently used in women. Many of these drugs/supplements have been very beneficial in males as well, and include hormones, bisphosphonates, antibodies, protein inhibitors, and nutritional supplements (Figure 2). Pharmacologic options for treating osteoporosis in men are listed in Table 1.

\section{Hormones}

Hormone therapy, especially estrogen, has been widely used to treat osteoporosis in women. Testosterone supplementation is also used in men, because a decrease in testosterone is linked to decreased bone mass. With such therapy, sitespecific improvement has been reported in some cases, with benefits only at the spine and not at the hip. ${ }^{80,81}$ Moreover, treatment with testosterone not only increased $\mathrm{BMD}^{82}$ but also increased prostate gland size and prostate specific antigen (PSA) levels. However, the prostate size is not affected when testosterone was given with finasteride (inhibitor of 5alpha reductase), therefore in these patients androgen replacement therapy was effective. ${ }^{52}$ It is important to note that testosterone treatment should be given only to those who have low levels of testosterone and need agents that will prevent fractures. ${ }^{80,83}$

The only anabolic bone agent approved by the US Food and Drug Administration for prevention and treatment of osteoporosis is teriparatide, a truncated parathyroid hormone. It may be one option for treating osteoporosis in men because it is associated with major gains in BMD at the lumbar spine, but less at the hip. ${ }^{4,14,80,84-86}$ Bone formation markers also increased with this treatment, and the risk of fracture reduced by $51 \% .{ }^{87}$ In patients with existing vertebral fractures, the risk went down to $13: 1$. However, continuous treatment with teriparatide is not recommended because of several side effects. Combination therapy using bisphosphonates and teriparatide did not increase BMD, however, patients on teriparatide therapy alone showed significantly increased BMD, in the lumbar and femur neck, although the BMT were similar in both groups (combined and teriparatide groups). ${ }^{88}$ At this point in time, the Food and Drug Administration has approved the use of teriparatide only for 24 months. After cessation of teriparatide, patients show a gradual decrease in BMD unless they are put on other medications. ${ }^{87}$ Although combination treatment with alendronate was not encouraging, administration of alendronate after teriparatide treatment maintained BMD, so sequential treatment is recommended. ${ }^{86,89,90}$ Whenever treatment with teriparatide was restarted, there was an increase in BMD. ${ }^{91}$ 


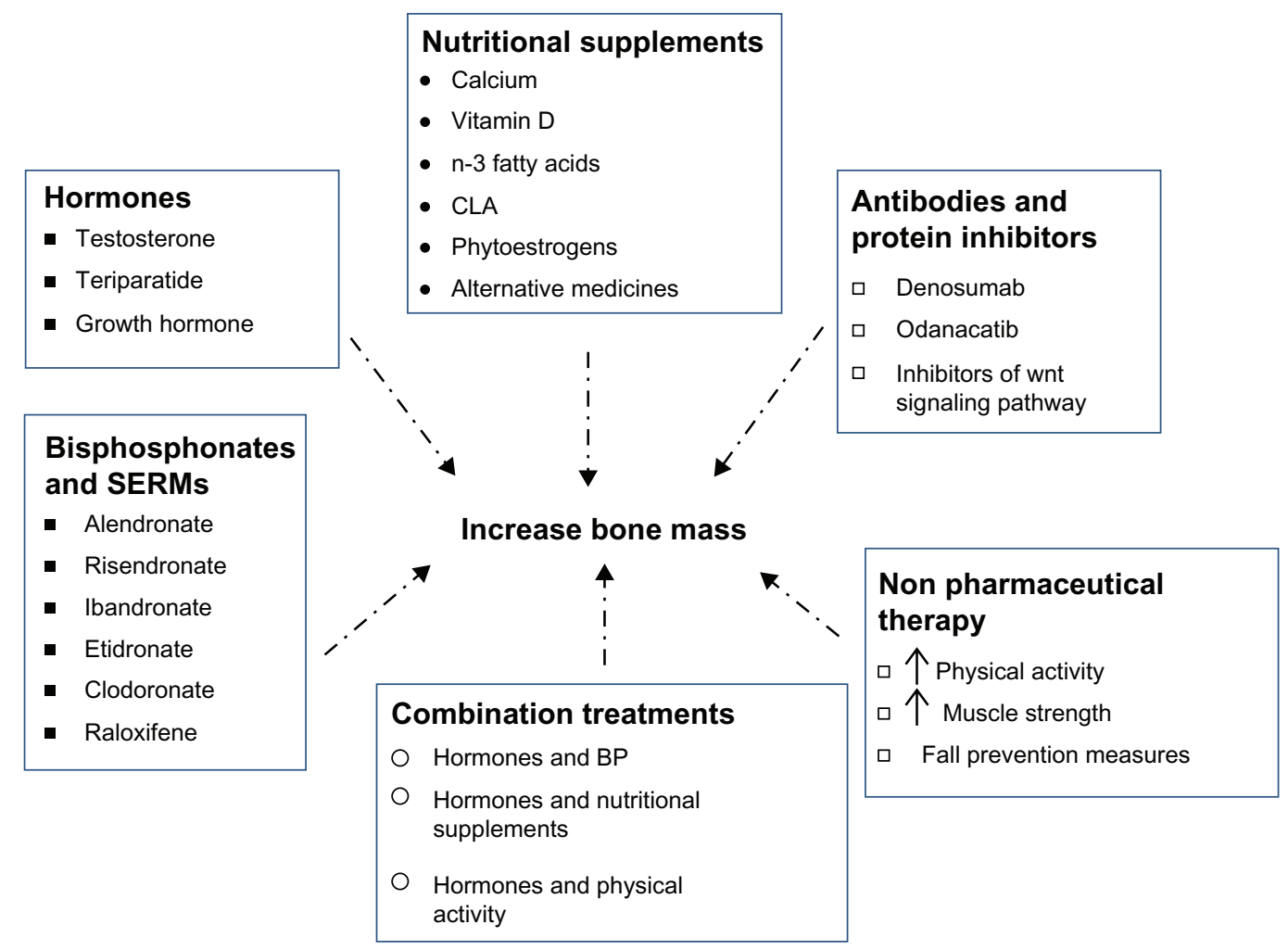

Figure 2 Treatment options for osteoporosis in men.

Abbreviations: BP, bisphosphonates; CLA, conjugated linoleic acid; SERMs, selective estrogen receptor modulators; $\uparrow$, increase.

Table I Pharmacological options available for treating osteoporosis in men

\begin{tabular}{|c|c|c|c|c|}
\hline Drug & Dosage/Frequency & Advantages & Side effects & References \\
\hline \multicolumn{5}{|l|}{ Hormones } \\
\hline Testosterone & & - Hypogonadal men, & Fluid retention, increased & $59,81,84$ \\
\hline Intramuscular & $200 \mathrm{mg} /$ every 2 weeks & BMD at lumbar vertebrae & blood pressure & \\
\hline Skin patch & $5 \mathrm{mg}$ daily & & & \\
\hline Gel & $50 \mathrm{mg} / 5 \mathrm{~g}$ daily & & & \\
\hline Parathyroid hormone & & $\begin{array}{l}\text { BMD, bone formation } \\
\text { markers }\end{array}$ & $\begin{array}{l}\text { Dizziness, nausea, palpitations, } \\
\text { hypercalcemia }\end{array}$ & $85-88$ \\
\hline Calcitonin & & $\begin{array}{l}\text { BMD of lumbar and } \\
\text { femoral neck }\end{array}$ & Dizziness, nausea, pain & $92,93,109$ \\
\hline \multicolumn{5}{|c|}{ Selective estrogen receptor modulator } \\
\hline Raloxifene & & 1 Bone mass & & 94,95 \\
\hline \multicolumn{5}{|l|}{ Bisphosphonates } \\
\hline Alendronate & 10 mg daily or 70 mg weekly & $\begin{array}{l}\text { BMD in vertebrae, } \\
\text { femoral neck }\end{array}$ & Gl tract intolerance & 88,91 \\
\hline Risendronate & $\begin{array}{l}5 \mathrm{mg} \text { daily or } 35 \mathrm{mg} \text { weekly or } \\
75 \mathrm{mg} \text { monthly ( } 2 \text { consecutive } \\
\text { days) or } 150 \mathrm{mg} \text { monthly }\end{array}$ & Bone mass & Gl tract intolerance & 14 \\
\hline Etidronate & $400 \mathrm{mg}$ daily & $\begin{array}{l}\text { - BMD in lumbar } \\
\text { vertebrae }\end{array}$ & $\begin{array}{l}\text { Gl tract intolerance, joint, bone, } \\
\text { and muscle pain, severe diarrhea, } \\
\text { jaw pain, numbness or swelling, } \\
\text { hives, swelling of mouth and throat }\end{array}$ & 98 \\
\hline Ibandronate & $\begin{array}{l}2.5 \text { mg daily or I } 50 \mathrm{mg} \\
\text { monthly or } 3 \mathrm{mg} \text { every } \\
3 \text { months (IV) }\end{array}$ & $\begin{array}{l}\text { BMD spine, } \\
\text { trochanter, femur neck }\end{array}$ & $\begin{array}{l}\text { GI tract intolerance, flu-like } \\
\text { symptoms, osteonecrosis of jaw }\end{array}$ & 99,102 \\
\hline Zoledronate & 5 mg yearly (IV) & Bone mass & $\begin{array}{l}\text { Flu-like symptoms, } \\
\text { osteonecrosis of jaw }\end{array}$ & $101,103,104,118$ \\
\hline
\end{tabular}

Abbreviations: IV, intravenously; GI, gastrointestinal; BMD. bone mineral density; 1 , increase. 
Another hormone that regulates circulating calcium is calcitonin. This hormone is a powerful inhibitor of osteoclasts. Administration of this agent is nasal, and it is reported to increase BMD at the lumbar spine and femoral neck but not at the proximal femur. ${ }^{4,14,82,86,92,93}$ During the last decade, calcitonin has been tested as a treatment option for osteoporosis in men. ${ }^{92,93}$ Growth hormone would also be beneficial to patients who are growth hormone-deficient.

Administration of hormones like testosterone, parathyroid hormone, and calcitonin may be useful for preventing bone loss and increasing bone mass. However, such treatment options should be used on an individual basis. Outcomes are dependent on the initial hormone status in some cases, while sequential treatment may be important in others.

\section{Selective estrogen receptor modulators}

Selective estrogen receptor modulators bind to estrogen receptors and have estrogen-like activity in bone. Raloxifene has been shown to increase bone mass and decrease urinary and circulating bone resorption markers. ${ }^{94,95}$ However, use of these agents may be limited to men with prostate cancer.

\section{Bisphosphonates}

Bisphosphonates are recommended for treating osteoporosis in men. ${ }^{4,80,86}$ Alendronate (Fosamax ${ }^{\circledR}$, Merck, Whitehouse Station, NJ, USA) improves BMD at the vertebrae and femoral neck in both eugonadal and hypogonadal men, with significant reductions in the incidence of vertebral fractures and less height loss. ${ }^{14,82,96,97}$ Other bisphosphonates like risendronate (Actonel $^{\circledR}$, Warner Chilcott, Dublin, Ireland) and ibandronate (Boniva $^{\circledR}$, Genentech Inc, South San Francisco, CA, USA) are also options for treating osteoporosis in men. ${ }^{14}$ Intermittent etidronate (Didronel ${ }^{\circledR}$, Warner Chilcott, Dublin, Ireland) therapy increases BMD at the lumbar spine by $3 \%$, with smaller increases at the hip $(0.7 \%)$ in patients with secondary osteoporosis. ${ }^{82,98}$ Ibandronate, another bisphosphonate, when given intravenously in combination with calcium and vitamin D supplementation increased BMD at the spine, femoral neck, and trochanter in a small study of 14 individuals. ${ }^{99}$ In yet another study, administration of ibandronate increased BMD at the lumbar vertebrae and hip in men and significantly reduced the risk of vertebral fractures. ${ }^{100}$ Zoledronate (Zometa ${ }^{\circledR}$, Zomera ${ }^{\circledR}$, Aclasta $^{\circledR}$, Reclast ${ }^{\circledR}$, Novartis, Basel, Switzerland) may be an alternative (administered intravenously, which may be better than the oral route for bisphosphonates) and is shown to be as effective as other bisphosphonates..$^{14,101-104}$ Bisphosphonates have been shown to be effective therapeutic agents for patients with osteoporosis, but there are certain limitations in using them. Many patients show tolerance, and each of the oral bisphosphonates has very strict and specific guidelines for dosage. However, great strides have been made in developing drugs that can be taken daily, weekly, monthly, or even yearly.

\section{Antibodies and protein inhibitors}

A recent trend in drug development has focused on targeting important proteins involved in development of osteoporosis. Specific antibodies and inhibitors of these proteins have been developed, and are listed in Table 2 . RANKL stimulates osteoclastogenesis and increases bone resorption. Denosumab, a monoclonal antibody against RANKL, is one of the newer medications that is available as a therapeutic option. ${ }^{14,94,105,106}$ It decreases bone resorption, thereby decreasing bone loss. This antibody should be taken with caution because it can affect the immune system, leading to infections.

Another protein, cathepsin K, which is expressed in osteoclasts and is capable of releasing minerals from bone, has

Table 2 Biological therapy possibilities for treating osteoporosis in men

\begin{tabular}{|c|c|c|c|c|}
\hline Antibodies & Target & Advantages & Disadvantages & References \\
\hline Denosumab & RANKL & Bone resorption & $\begin{array}{l}\text { Reduces immunity, skin rashes, } \\
\text { high cholesterol }\end{array}$ & $14,94,105,106$ \\
\hline Odanacatib & Cathepsin K & $\begin{array}{l}\text { Bone resorption markers, } \\
\text { BMD spine and hip }\end{array}$ & Not known & $94,107,108$ \\
\hline \multicolumn{5}{|l|}{ Inhibitors } \\
\hline AMG 785 & Sclerostin & - Bone formation markers, BMD & Oncogenic, calcium homeostasis, & $105,109-112$ \\
\hline Specific to DKKI & DKKI & Bone formation & uncontrolled bone formation & \\
\hline Specific to Frp & Frp & May bone loss & leading to complications & \\
\hline Lithium & GSK-3 & - BMD & & \\
\hline $60328|-3|-8$ & GSK-3 & Bone formation markers, bone strength & & \\
\hline 6-bromoindirubin-3'-oxime & GSK-3 & Glucocorticoid-induced bone loss & & \\
\hline AR28 & GSK-3 & Bone mass & & \\
\hline
\end{tabular}

Abbreviations: BMD, bone mineral density; DKKI, Dickkopf I; Frp, frizzled-related proteins; RANKL, receptor activated nuclear factor kappa B ligand; $\mathbf{1}$, increase; GSK-3, glycogen synthase kinase 3. 
also been targeted. Odanacatib, an inhibitor of cathepsin K, decreased bone resorption markers and increased BMD at the spine and hip over two years. ${ }^{94,107}$ This therapy is recommended in men because it increases BMD and decreases the fracture rate in patients with prostate cancer, delays the time to the first skeletal-related event, and increases bone metastasis-free survival. ${ }^{108}$

The wingless-type and integrase 1 (Wnt) signaling pathway regulates osteoblastogenesis, and inhibitors of some of these proteins can be considered as potential drug targets. ${ }^{109}$ When sclerostin (a natural antagonist of the Wnt signaling pathway) is inhibited, the anabolic properties of bone are increased in animal models. ${ }^{110}$ In healthy men, inhibition of sclerostin using AMG 785 significantly increased bone formation markers and BMD, while significantly decreasing bone resorption markers. ${ }^{111}$ A polymorphism of the gene coding for sclerostin showed site-specific association with BMD of the femoral neck. ${ }^{105}$ Dickkopf 1 , another endogenous inhibitor of the Wnt signaling pathway, has also been investigated, and a Dickkopf 1 antagonist was found to increase bone formation. ${ }^{109}$ Another possible target is the frizzled-related proteins, which are also inhibitors of the Wnt signaling pathway. Studies in mice have shown that overexpression of serum frizzled-related proteins decreases bone mass and inhibits osteoblast function as well as the anabolic effects of parathyroid hormone. ${ }^{109,112}$ Other possible targets that have been reported include glycogen synthase kinase 3 (GSK-3), another endogenous inhibitor of the Wnt signaling pathway. ${ }^{109}$ Further, several inhibitors of GSK-3, including lithium, 603281-31-8, 6-bromoindirubin-3'-oxime, and AR28, have been tested. ${ }^{109}$ However, a major concern in using Wnt signaling pathway antagonists is the oncogenic effects resulting from inhibition of this pathway. ${ }^{109}$ Targeting specific proteins in the metabolic pathway related to bone metabolism is a novel approach, but extreme caution is needed because many of these proteins are not just part of bone metabolism but also play a key role in other important pathways. Therefore, when these drugs are used, a balanced approach that increases the benefits but decreases other health complications and side effects must be taken into consideration. This approach is very important in treating osteoporosis, mainly because a majority of the patients are elderly, moreover, with increase in life expectancy the quality of life should also be improved.

\section{Nutritional supplementation}

Several nutritional supplements are also implicated in maintaining bone health. These include minerals like calcium, vitamins, fatty acids, and herbal products (Table 3 ). Nutritional supplementation with calcium and vitamin D to increase calcium absorption is commonly prescribed to patients with osteoporosis, including men. ${ }^{4,97,113-117}$ Calcium and vitamin D monotherapy has been reported to reduce hip fractures. ${ }^{14,80,118,119}$ It is reported that community-dwelling elders are likely to have sufficient intake of calcium and vitamin D, but institutionalized elders showed calcium and vitamin D deficiency. Intermittent monofluorophosphate and calcium increased bone density and decreased the risk of vertebral fractures in upper middle aged men (mean age 53). ${ }^{120}$ Irrespective of ethnic background, vitamin D supplementation is recommended. ${ }^{16}$ Supplementation with calcium and vitamin D, in addition to helping bone, decreases hyperthyroidism and improves muscle strength, function, and balance. ${ }^{56-58}$

Other nutritional supplements that have shown promise in reducing bone loss are n-3 fatty acids, conjugated linoleic acid, soy isoflavones, and some herbal compounds. Several studies of n-3 fatty acids have reported benefits on bones in male animal models by decreasing prostaglandin $2^{121,122}$ and bone resorption as well as increasing BMD at the lumbar vertebrae ${ }^{123}$ and tibia. ${ }^{124} \mathrm{n}-3$ fatty acids benefit bone mainly by reducing bone turnover. ${ }^{125}$ In men, a positive correlation has been found between consumption of docosahexaenoic acid and peak BMD. ${ }^{126}$ Another fatty acid, known as conjugated linoleic acid and commonly found in milk and dairy products, increased bone mass in male

Table 3 Possible nutritional supplements for the prevention and treatment of osteoporosis in men

\begin{tabular}{|c|c|c|}
\hline Supplements & Evidence & References \\
\hline Calcium & $\begin{array}{l}\text { Men, postmenopausal } \\
\text { women }\end{array}$ & $4,14,80,97,1 \mid 3-120$ \\
\hline \multicolumn{3}{|l|}{ Vitamins } \\
\hline Vitamin D & $\begin{array}{l}\text { Men, postmenopausal } \\
\text { women }\end{array}$ & $16,56-58,1 \mid 3-120$ \\
\hline \multicolumn{3}{|l|}{ Fatty acids } \\
\hline n-3 fatty acids & Preclinical & $121,122,125$ \\
\hline $\begin{array}{l}\text { Conjugated linoleic } \\
\text { acid }\end{array}$ & $\begin{array}{l}\text { Preclinical } \\
\text { (males, females) }\end{array}$ & 126,127 \\
\hline \multicolumn{3}{|l|}{ Herbal products } \\
\hline Soy isoflavones & $\begin{array}{l}\text { Preclinical, } \\
\text { postmenopausal } \\
\text { women }\end{array}$ & 116,128 \\
\hline Black cohosh & & 116,129 \\
\hline Fructus linguistri lucidi & Preclinical & \\
\hline Cissus quadrangularis & Preclinical & \\
\hline Prunes & $\begin{array}{l}\text { Preclinical, } \\
\text { postmenopausal } \\
\text { women }\end{array}$ & $|30| 3 \mid$, \\
\hline
\end{tabular}


Table 4 Nonpharmacologic therapies available for men

\begin{tabular}{|c|c|c|}
\hline Therapies & Benefits & References \\
\hline Exercise & - Muscle and bone mass & 80 \\
\hline $\begin{array}{l}\text { Muscle } \\
\text { strengthening }\end{array}$ & $\begin{array}{l}\text { Muscle strength, frailty, } \\
\text { bone mass }\end{array}$ & 80 \\
\hline \multicolumn{3}{|l|}{ Fall prevention } \\
\hline Vision & Visibility, falls & 132,133 \\
\hline Hearing & $\begin{array}{l}\text { Improved hearing } \\
\text { ability accidents }\end{array}$ & \\
\hline Neurologic & Treatment for depression & \\
\hline factors & $\begin{array}{l}\text { improves health condition and } \\
\text { falls and accidents }\end{array}$ & \\
\hline Safety features & Installing hand rails falls & \\
\hline \multicolumn{3}{|l|}{ Healthy lifestyle } \\
\hline Diet & Balanced nutrition bone loss & 132,133 \\
\hline Tobacco & Bone mineral density & \\
\hline Alcohol & Bone mass & \\
\hline
\end{tabular}

Abbreviations: $\boldsymbol{*}$, increase; $\boldsymbol{\$}$, decrease.

mice. ${ }^{127}$ Phytoestrogens like soy isoflavones increased bone mass in orchidectomized rats, primarily by increasing bone turnover markers and the microarchitecture of trabecular bone. ${ }^{128}$ Ipriflavone, a synthetic isoflavone, is also beneficial in maintaining bone mass. ${ }^{116}$

Herbal supplements and alternative medicines, including vitamin E, black cohosh, red clover, Fructus linguistri lucidi, Cissus quadrangularis, and prunes, have shown to have boneprotective properties in preclinical studies. ${ }^{116,129-131}$ Although many of these studies have been conducted in females, there is a high probability that these will also be beneficial to men. More systematic studies using these promising compounds may be worth pursuing to develop safer and more costeffective treatment options.

Apart from drug interventions, nonpharmacologic therapies (Table 4) including exercise and muscle-strengthening strategies are also recommended, eg, increasing physical activity in patients with osteoporosis.$^{80}$ Fall prevention measures such as checking vision and hearing, neurologic assessment, and installing safety features in the home should be part of the treatment regimen. ${ }^{132,133}$ In addition, leading a healthy lifestyle, including eating healthy foods, avoiding tobacco, and limiting alcohol consumption is also recommended. ${ }^{133}$

\section{Conclusion}

Traditionally, osteoporosis was considered a disease that affects only women. However, a little over two decades ago, osteoporosis came to be recognized as a disease that is also prevalent in elderly men and with bleak survival outcomes following fracture. As the population is moving toward an increased life span, it is logical to predict that the number of patients with osteoporosis will increase. In individuals suffering from osteoporosis, living conditions are highly compromised, apart from the financial burden on society.

Although we have learned a lot about osteoporosis from studies in women, there are basic differences between women and men which need to be addressed, hence a need for more studies in men. In particular, assessment must include standards determined for men followed by treatment options. Evidence from existing studies shows most men do not get treated for osteoporosis after a hip fracture. Patients should be screened during initial evaluation for serum calcium, phosphorus, creatine, alkaline phosphatase, vitamin $\mathrm{D}$, liver transaminases, thyroid-stimulating hormone, total testosterone, 25-hydroxyvitamin $\mathrm{D}$, parathyroid hormone, prostate-specific antigen, bone turnover markers (ie, terminal telopeptide and procollagen type 1 amino-terminal propeptide), glucocorticoid use, and family history in order to decide on the correct treatment options. ${ }^{4,88,106}$ Currently there are very few clinical studies on osteoporosis in men, limiting the understanding and development of the disease as well as the therapeutic options. ${ }^{134}$ Dual X-ray absorptiometry, high resolution quantitated computed tomography with finite element analysis, and magnetic resonance imaging are common methods for detection of the disease. ${ }^{62,94}$ Use of these diagnostic tools in men after a certain age will help in identifying those at risk so that preventive measures to avoid fractures can be implemented. Moreover, the focus in identifying new drugs for preventing and treating osteoporosis should also include reducing or eliminating harmful side effects and be more cost-effective.

\section{Acknowledgment}

The author thanks Jorge F Navarro and Mahaboob MH Khan for their assistance in literature collection for this review.

\section{Disclosure}

The author has no conflicts of interest to report in this work.

\section{References}

1. Hannan MT, Felson DT, Dawson-Hughes B, et al. Risk factors for longitudinal bone loss in elderly men and women: the Framingham Osteoporosis Study. J Bone Miner Res. 2000;15(4):710-720.

2. Khosla S. Update in male osteoporosis. J Clin Endocrinol Metab. 2010;95(1):3-10.

3. Melton LJ 3rd, Chrischilles EA, Cooper C, Lane AW, Riggs BL. Perspective. How many women have osteoporosis? J Bone Miner Res. 1992;7(9):1005-1010.

4. Binkley N. A perspective on male osteoporosis. Best Pract Res Clin Rheumatol. 2009;23(6):755-768.

5. Edelstein OE. What do Israeli osteoporotic men know and do about their disease? J Osteoporos. 2011;2011:719862. 
6. McLeod KM, Johnson CS. A systematic review of osteoporosis health beliefs in adult men and women. J Osteoporos. 2011;2011:197454.

7. Solimeo SL. Living with a 'women's disease': risk appraisal and management among men with osteoporosis. J Mens health. 2011;8(3): 185-191.

8. Madeo B, Zirilli L, Caffagni G, et al. The osteoporotic male: overlooked and undermanaged? Clin Interv Aging. 2007;2(3):305-312.

9. Rao SS, Budhwar N, Ashfaque A. Osteoporosis in men. Am Fam Physician. 2010;82(5):503-508.

10. Seeman E. Reduced bone formation and increased bone resorption: rational targets for the treatment of osteoporosis. Osteoporos Int 2003;14 Suppl 3:S2-S8.

11. Lambert JK, Zaidi M, Mechanick JI. Male osteoporosis: epidemiology and the pathogenesis of aging bones. Curr Osteoporos Rep. 2011;9(4):229-236.

12. Compston J, Cooper A, Cooper C, et al. Guidelines for the diagnosis and management of osteoporosis in postmenopausal women and men from the age of 50 years in the UK. Maturitas. 2009;62(2):105-108.

13. National Osteoporosis Foundation. Making a diagnosis. Available from http://www.nof.org/articles/8. Accessed October 16, 2012.

14. Gates BJ, Das S. Management of osteoporosis in elderly men. Maturitas. 2011;69(2):113-119

15. Ryan CS, Petkov VI, Adler RA. Osteoporosis in men: the value of laboratory testing. Osteoporos Int. 2010;22(6):1845-1853.

16. Dawson-Hughes B. Racial/ethnic considerations in making recommendations for vitamin $\mathrm{D}$ for adult and elderly men and women. $\mathrm{Am} \mathrm{J}$ Clin Nutr. 2004;80(Suppl 6):1763S-1766S.

17. Leder BZ, LeBlanc KM, Schoenfeld DA, Eastell R, Finkelstein JS. Differential effects of androgens and estrogens on bone turnover in normal men. J Clin Endocrinol Metab. 2003;88(1):204-210.

18. Mohr BA, Guay AT, O’Donnell AB, McKinlay JB. Normal, bound and nonbound testosterone levels in normally ageing men: results from the Massachusetts Male Ageing Study. Clin Endocrinol (Oxf). 2005;62(1):64-73.

19. Feldman HA, Longcope C, Derby CA, et al. Age trends in the level of serum testosterone and other hormones in middle-aged men: longitudinal results from the Massachusetts Male Aging Study. J Clin Endocrinol Metab. 2002;87(2):589-598.

20. Morley JE, Kaiser FE, Perry HM 3rd, et al. Longitudinal changes in testosterone, luteinizing hormone, and follicle-stimulating hormone in healthy older men. Metabolism. 1997;46(4):410-413.

21. Muller M, den Tonkelaar I, Thijssen JH, Grobbee DE, van der Schouw YT. Endogenous sex hormones in men aged $40-80$ years. Eur $J$ Endocrinol. 2003;149(6):583-589.

22. Svartberg J, Midtby M, Bonaa KH, Sundsfjord J, Joakimsen RM, Jorde R. The associations of age, lifestyle factors and chronic disease with testosterone in men: the Tromso Study. Eur J Endocrinol. 2003;149(2):145-152.

23. Vermeulen A, Kaufman JM, Giagulli VA. Influence of some biological indexes on sex hormone-binding globulin and androgen levels in aging or obese males. J Clin Endocrinol Metab. 1996;81(5):1821-1826.

24. Ferrini RL, Barrett-Connor E. Sex hormones and age: a cross-sectional study of testosterone and estradiol and their bioavailable fractions in community-dwelling men. Am J Epidemiol. 1998;147(8):750-754.

25. Litman HJ, Bhasin S, Link CL, Araujo AB, McKinlay JB. Serum androgen levels in black, Hispanic, and white men. J Clin Endocrinol Metab. 2006;91(11):4326-4334.

26. Yeap BB. Testosterone and ill-health in aging men. Nat Clin Pract Endocrinol Metab. 2009;5(2):113-121.

27. Khosla S, Amin S, Orwoll E. Osteoporosis in men. Endocr Rev. 2008;29(4):441-464.

28. Sinnesael M, Boonen S, Claessens F, Gielen E, Vanderschueren D. Testosterone and the male skeleton: a dual mode of action. J Osteoporos. 2011;2011:240328.

29. LeBlanc ES, Nielson CM, Marshall LM, et al. The effects of serum testosterone, estradiol, and sex hormone binding globulin levels on fracture risk in older men. J Clin Endocrinol Metab. 2009;94(9):3337-3346.
30. Kurland ES, Cosman F, McMahon DJ, Rosen CJ, Lindsay R, Bilezikian JP. Parathyroid hormone as a therapy for idiopathic osteoporosis in men: effects on bone mineral density and bone markers. J Clin Endocrinol Metab. 2000;85(9):3069-3076.

31. Van Pottelbergh I, Goemaere S, Zmierczak H, Kaufman JM. Perturbed sex steroid status in men with idiopathic osteoporosis and their sons. J Clin Endocrinol Metab. 2004;89(10):4949-4953.

32. Trouvin AP, Goeb V. Receptor activator of nuclear factor-kappaB ligand and osteoprotegerin: maintaining the balance to prevent bone loss. Clin Interv Aging. 2011;5:345-354.

33. Israeli RS, Ryan CW, Jung LL. Managing bone loss in men with locally advanced prostate cancer receiving androgen deprivation therapy. J Urol. 2008;179(2):414-423.

34. Liu H, Paige NM, Goldzweig CL, et al. Screening for osteoporosis in men: a systematic review for an American College of Physicians guideline. Ann Intern Med. 2008;148(9):685-701.

35. Lopez AM, Pena MA, Hernandez R, Val F, Martin B, Riancho JA. Fracture risk in patients with prostate cancer on androgen deprivation therapy. Osteoporos Int. 2005;16(6):707-711.

36. Shahinian VB, Kuo YF, Freeman JL, Goodwin JS. Risk of fracture after androgen deprivation for prostate cancer. $N$ Engl $J$ Med. 2005;352(2):154-164.

37. Diamond TH, Higano CS, Smith MR, Guise TA, Singer FR. Osteoporosis in men with prostate carcinoma receiving androgendeprivation therapy: recommendations for diagnosis and therapies. Cancer. 2004;100(5):892-899.

38. Daniell HW, Dunn SR, Ferguson DW, Lomas G, Niazi Z, Stratte PT. Progressive osteoporosis during androgen deprivation therapy for prostate cancer. J Urol. 2000;163(1):181-186.

39. Kiratli BJ, Srinivas S, Perkash I, Terris MK. Progressive decrease in bone density over 10 years of androgen deprivation therapy in patients with prostate cancer. Urology. 2001;57(1):127-132.

40. Sardone LD, Renlund R, Willett TL, Fantus IG, Grynpas MD. Effect of rosiglitazone on bone quality in a rat model of insulin resistance and osteoporosis. Diabetes. 2011;60(12):3271-3278.

41. Debiais F. Thiazolidinediones: antidiabetic agents with effects on bone. Joint Bone Spine. 2009;76(3):221-223.

42. Grey A. Thiazolidinedione-induced skeletal fragility - mechanisms and implications. Diabetes Obes Metab. 2009;11(4):275-284.

43. Rosen CJ. The rosiglitazone story - lessons from an FDA Advisory Committee meeting. N Engl J Med. 2007;357(9):844-846.

44. Aubert RE, Herrera V, Chen W, Haffner SM, Pendergrass M. Rosiglitazone and pioglitazone increase fracture risk in women and men with type 2 diabetes. Diabetes Obes Metab. 2010;12(8):716-721.

45. Chakreeyarat S, Saetung S, Chailurkit LO, et al. Elevated vitamin D status in postmenopausal women on thiazolidinediones for type 2 diabetes. Endocrine. 2010;39(3):278-282.

46. Carruthers M, Trinick TR, Jankowska E, Traish AM. Are the adverse effects of glitazones linked to induced testosterone deficiency? Cardiovasc Diabetol. 2008;7:30.

47. Lecka-Czernik B. Bone loss in diabetes: use of antidiabetic thiazolidinediones and secondary osteoporosis. Curr Osteoporos Rep. 2010;8(4):178-184

48. Soroceanu MA, Miao D, Bai XY, Su H, Goltzman D, Karaplis AC. Rosiglitazone impacts negatively on bone by promoting osteoblast/ osteocyte apoptosis. J Endocrinol. 2004;183(1):203-216.

49. Szulc P. Biochemical bone turnover markers and osteoporosis in older men: where are we? J Osteoporos. 2011;2011:704015.

50. Meier C, Nguyen TV, Center JR, Seibel MJ, Eisman JA. Bone resorption and osteoporotic fractures in elderly men: the Dubbo Osteoporosis Epidemiology study. J Bone Miner Res. 2005;20(4): 579-587.

51. Theiler R, Stahelin HB, Kranzlin M, Tyndall A, Bischoff HA. High bone turnover in the elderly. Arch Phys Med Rehabil. 1999;80(5): 485-489.

52. Adler RA. Epidemiology and pathophysiology of osteoporosis in men. Curr Osteoporos Rep. 2006;4(3):110-115. 
53. Herrara AL-EA, Mateo J, Gil J, Ibarz E, Garcia L. Male osteoporosis: a review. World J Orthop. 2012;3(12):223-234.

54. Shimizu Y, Sakai A, Menuki K, et al. Reduced bone formation in alcohol-induced osteopenia is associated with elevated $\mathrm{p} 21$ expression in bone marrow cells in aldehyde dehydrogenase 2-disrupted mice. Bone. 2011;48(5):1075-1086.

55. Al-oanzi ZH, Tuck SP, Raj N, et al. Assessment of vitamin D status in male osteoporosis. Clin Chem. 2006;52(2):248-254.

56. Bischoff-Ferrari HA, Conzelmann M, Stahelin HB, et al. Is fall prevention by vitamin $\mathrm{D}$ mediated by a change in postural or dynamic balance? Osteoporos Int. 2006;17(5):656-663.

57. Gielen E, Boonen S, Vanderschueren D, et al. Calcium and vitamin D supplementation in men. J Osteoporos. 2011;2011:875249.

58. Gupta R, Sharma U, Gupta N, et al. Effect of cholecalciferol and calcium supplementation on muscle strength and energy metabolism in vitamin D-deficient Asian Indians: a randomized, controlled trial. Clin Endocrinol (Oxf). 2010;73(4):445-451.

59. Behre HM, Kliesch S, Leifke E, Link TM, Nieschlag E. Long-term effect of testosterone therapy on bone mineral density in hypogonadal men. J Clin Endocrinol Metab. 1997;82(8):2386-2390.

60. Farhat G, Yamout B, Mikati MA, Demirjian S, Sawaya R, El-Hajj Fuleihan G. Effect of antiepileptic drugs on bone density in ambulatory patients. Neurology. 2002;58(9):1348-1353.

61. Scane AC, Francis RM, Sutcliffe AM, Francis MJ, Rawlings DJ, Chapple CL. Case-control study of the pathogenesis and sequelae of symptomatic vertebral fractures in men. Osteoporos Int. 1999;9(1): 91-97.

62. Amin S, Khosla S. Sex- and age-related differences in bone microarchitecture in men relative to women assessed by high-resolution peripheral quantitative computed tomography. J Osteoporos. 2012;2012: 129760.

63. Gennari L, Bilezikian JP. Osteoporosis in men: pathophysiology and treatment. Curr Rheumatol Rep. 2007;9(1):71-77.

64. Khosla S, Riggs BL, Atkinson EJ, et al. Effects of sex and age on bone microstructure at the ultradistal radius: a population-based noninvasive in vivo assessment. J Bone Miner Res. 2006;21(1):124-131.

65. Sode M, Burghardt AJ, Kazakia GJ, Link TM, Majumdar S. Regional variations of gender-specific and age-related differences in trabecular bone structure of the distal radius and tibia. Bone. 2010;46(6): $1652-1660$.

66. Macdonald HM, Nishiyama KK, Kang J, Hanley DA, Boyd SK. Age-related patterns of trabecular and cortical bone loss differ between sexes and skeletal sites: a population-based HR-pQCT study. $J$ Bone Miner Res. 2010;26(1):50-62.

67. Burghardt AJ, Kazakia GJ, Ramachandran S, Link TM, Majumdar S. Age- and gender-related differences in the geometric properties and biomechanical significance of intracortical porosity in the distal radius and tibia. J Bone Miner Res. 2009;25(5):983-993.

68. Russo CR, Lauretani F, Seeman E, et al. Structural adaptations to bone loss in aging men and women. Bone. 2006;38(1):112-118.

69. Seeman E. During aging, men lose less bone than women because they gain more periosteal bone, not because they resorb less endosteal bone. Calcif Tissue Int. 2001;69(4):205-208.

70. Seeman E. The structural and biomechanical basis of the gain and loss of bone strength in women and men. Endocrinol Metab Clin North Am. 2003;32(1):25-38.

71. Vanderschueren D, Vandenput L, Boonen S, Lindberg MK, Bouillon R, Ohlsson C. Androgens and bone. Endocr Rev. 2004;25(3):389-425.

72. Callewaert F, Venken K, Ophoff J, et al. Differential regulation of bone and body composition in male mice with combined inactivation of androgen and estrogen receptor-alpha. FASEB J. 2009;23(1):232-240.

73. Sims NA, Dupont $S$, Krust A, et al. Deletion of estrogen receptors reveals a regulatory role for estrogen receptors-beta in bone remodeling in females but not in males. Bone. 2002;30(1):18-25.

74. Olson LE, Ohlsson C, Mohan S. The role of GH/IGF-I-mediated mechanisms in sex differences in cortical bone size in mice. Calcif Tissue Int. 2010;88(1):1-8.
75. National Osteoporosis Foundation. Just for men. Available from: http:// www.nof.org/articles/236. Accessed October 15, 2012.

76. Bass E, French DD, Bradham DD, Rubenstein LZ. Risk-adjusted mortality rates of elderly veterans with hip fractures. Ann Epidemiol. 2007;17(7):514-519.

77. Cooper C, Campion G, Melton LJ 3rd. Hip fractures in the elderly: a world-wide projection. Osteoporos Int. 1992;2(6):285-289.

78. Johnell O, Kanis JA. An estimate of the worldwide prevalence and disability associated with osteoporotic fractures. Osteoporos Int. 2006;17(12):1726-1733.

79. Poor G, Atkinson EJ, Lewallen DG, O'Fallon WM, Melton LJ 3rd. Age-related hip fractures in men: clinical spectrum and short-term outcomes. Osteoporos Int. 1995;5(6):419-426.

80. Duque G, Troen BR. Understanding the mechanisms of senile osteoporosis: new facts for a major geriatric syndrome. J Am Geriatr Soc. 2008;56(5):935-941.

81. Snyder PJ, Peachey H, Hannoush P, et al. Effect of testosterone treatment on bone mineral density in men over 65 years of age. $J$ Clin Endocrinol Metab. 1999;84(6):1966-1972.

82. Licata A. Osteoporosis in men: suspect secondary disease first. Cleve Clin J Med. 2003;70(3):247-254.

83. Kanis JA, Bianchi G, Bilezikian JP, et al. Towards a diagnostic and therapeutic consensus in male osteoporosis. Osteoporos Int. 2011;22(11): 2789-2798.

84. Gruenewald DA, Matsumoto AM. Testosterone supplementation therapy for older men: potential benefits and risks. J Am Geriatr Soc. 2003;51(1):101-115.

85. Cusano NE, Costa AG, Silva BC, Bilezikian JP. Therapy of osteoporosis in men with teriparatide. J Osteoporos. 2011;2011:463675.

86. Girotra M, Rubin MR, Bilezikian JP. Anabolic skeletal therapy for osteoporosis. Arq Bras Endocrinol Metabol. 2006;50(4):745-754.

87. Kaufman JM, Orwoll E, Goemaere S, et al. Teriparatide effects on vertebral fractures and bone mineral density in men with osteoporosis: treatment and discontinuation of therapy. Osteoporos Int. 2005;16(5):510-516.

88. Finkelstein JS, Leder BZ, Burnett SM, et al. Effects of teriparatide, alendronate, or both on bone turnover in osteoporotic men. J Clin Endocrinol Metab. 2006;91(8):2882-2887.

89. Kurland ES, Heller SL, Diamond B, McMahon DJ, Cosman F, Bilezikian JP. The importance of bisphosphonate therapy in maintaining bone mass in men after therapy with teriparatide [human parathyroid hormone(1-34)]. Osteoporos Int. 2004;15(12):992-997.

90. Kraenzlin ME, Meier C. Parathyroid hormone analogues in the treatment of osteoporosis. Nat Rev Endocrinol. 2011;7(11):647-656.

91. Finkelstein JS, Hayes A, Hunzelman JL, Wyland JJ, Lee H, Neer RM. The effects of parathyroid hormone, alendronate, or both in men with osteoporosis. N Engl J Med. 2003;349(13):1216-1226.

92. Toth E, Csupor E, Meszaros S, et al. The effect of intranasal salmon calcitonin therapy on bone mineral density in idiopathic male osteoporosis without vertebral fractures - an open label study. Bone. 2005;36(1):47-51.

93. Trovas GP, Lyritis GP, Galanos A, Raptou P, Constantelou E. A randomized trial of nasal spray salmon calcitonin in men with idiopathic osteoporosis: effects on bone mineral density and bone markers. $J$ Bone Miner Res. 2002;17(3):521-527.

94. Honig S. Osteoporosis - new treatments and updates. Bull NYU Hosp Jt Dis. 2010;68(3):166-170.

95. Smith MR, Fallon MA, Lee H, Finkelstein JS. Raloxifene to prevent gonadotropin-releasing hormone agonist-induced bone loss in men with prostate cancer: a randomized controlled trial. J Clin Endocrinol Metab. 2004;89(8):3841-3846.

96. Gonnelli S, Cepollaro C, Montagnani A, et al. Alendronate treatment in men with primary osteoporosis: a three-year longitudinal study. Calcif Tissue Int. 2003;73(2):133-139.

97. Orwoll ES, Oviatt SK, McClung MR, Deftos LJ, Sexton G. The rate of bone mineral loss in normal men and the effects of calcium and cholecalciferol supplementation. Ann Intern Med. 1990;112(1):29-34. 
98. Anderson FH, Francis RM, Bishop JC, Rawlings DJ. Effect of intermittent cyclical disodium etidronate therapy on bone mineral density in men with vertebral fractures. Age Ageing. 1997;26(5): 359-365.

99. Lamy O, Sandini L, Pache I, Fatio S, Burnand J, Burckhardt P. Intravenous ibandronate in men with osteoporosis: an open pilot study over 2 years. $J$ Endocrinol Invest. 2003;26(8):728-732.

100. Boonen S, Reginster JY, Kaufman JM, et al. Fracture risk and zoledronic acid therapy in men with osteoporosis. $N$ Engl $J$ Med. 2012;367(18):1714-1723.

101. Piper PK Jr, Gruntmanis U. Management of osteoporosis in the aging male: focus on zoledronic acid. Clin Interv Aging. 2009;4:289-303.

102. Sewerynek E, Stuss M. The role of I.V. ibandronate administration in osteoporosis therapy. Endokrynol Pol. 2011;62(1):51-60.

103. Black DM, Delmas PD, Eastell R, et al. Once-yearly zoledronic acid for treatment of postmenopausal osteoporosis. $N$ Engl J Med. 2007;356(18):1809-1822.

104. Black DM, Reid IR, Boonen S, et al. The effect of 3 versus 6 years of zoledronic acid treatment of osteoporosis: a randomized extension to the HORIZON-Pivotal Fracture Trial (PFT). $J$ Bone Miner Res. 2012;27(2):243-254.

105. Piters E, de Freitas F, Nielsen TL, Andersen M, Brixen K, Van Hul W. Association study of polymorphisms in the SOST gene region and parameters of bone strength and body composition in both young and elderly men: data from the Odense Androgen Study. CalcifTissue Int. 2011;90(1):30-39.

106. Kaufman JM, Reginster JY, Boonen S, et al. Treatment of osteoporosis in men. Bone. 2012;53(1):134-144.

107. Gagnon C, Ebeling PR. Recent advances in managing osteoporosis. F1000 Med Rep. 2009;1:pii 96.

108. Morgans AK, Smith MR. RANKL-targeted therapies: the next frontier in the treatment of male osteoporosis. $J$ Osteoporos. 2011;2011:941310.

109. Baron R, Hesse E. Update on bone anabolics in osteoporosis treatment: rationale, current status, and perspectives. J Clin Endocrinol Metab. 2012;97(2):311-325.

110. Li X, Ominsky MS, Warmington KS, et al. Sclerostin antibody treatment increases bone formation, bone mass, and bone strength in a rat model of postmenopausal osteoporosis. $J$ Bone Miner Res. 2009;24(4):578-588.

111. Lewiecki EM. Sclerostin: a novel target for intervention in the treatment of osteoporosis. Discov Med. 2011;12(65):263-273.

112. Cho HY, Choi HJ, Sun HJ, et al. Transgenic mice overexpressing secreted frizzled-related proteins (sFRP) 4 under the control of serum amyloid P promoter exhibit low bone mass but did not result in disturbed phosphate homeostasis. Bone. 2010;47(2):263-271.

113. Dawson-Hughes B, Harris SS, Krall EA, Dallal GE. Effect of calcium and vitamin D supplementation on bone density in men and women 65 years of age or older. N Engl J Med. 1997;337(10): 670-676.

114. Trivedi DP, Doll R, Khaw KT. Effect of four monthly oral vitamin D3 (cholecalciferol) supplementation on fractures and mortality in men and women living in the community: randomised double blind controlled trial. BMJ. 2003;326(7387):469.

115. Compston J. Clinical and therapeutic aspects of osteoporosis. Eur J Radiol. 2009;71(3):388-391.

116. Moyad MA. Complementary/alternative therapies for reducing hot flashes in prostate cancer patients: reevaluating the existing indirect data from studies of breast cancer and postmenopausal women. Urology. 2002;59(4 Suppl 1):20-33.
117. Avenell A, Gillespie WJ, Gillespie LD, O’Connell D. Vitamin D and vitamin $\mathrm{D}$ analogues for preventing fractures associated with involutional and post-menopausal osteoporosis. Cochrane Database Syst Rev. 2009;2:CD000227.

118. Boonen S, Lips P, Bouillon R, Bischoff-Ferrari HA, Vanderschueren D, Haentjens P. Need for additional calcium to reduce the risk of hip fracture with vitamin $d$ supplementation: evidence from a comparative metaanalysis of randomized controlled trials. JClin Endocrinol Metab. 2007;92(4):1415-1423.

119. Tang BM, Eslick GD, Nowson C, Smith C, Bensoussan A. Use of calcium or calcium in combination with vitamin $\mathrm{D}$ supplementation to prevent fractures and bone loss in people aged 50 years and older: a meta-analysis. Lancet. 2007;370(9588):657-666.

120. Ringe JD, Dorst A, Kipshoven C, Rovati LC, Setnikar I. Avoidance of vertebral fractures in men with idiopathic osteoporosis by a three year therapy with calcium and low-dose intermittent monofluorophosphate. Osteoporos Int. 1998;8(1):47-52.

121. Watkins BA, Li Y, Lippman HE, Seifert MF. Omega-3 polyunsaturated fatty acids and skeletal health. Exp Biol Med (Maywood). 2001;226(6):485-497.

122. Fernandes G, Bhattacharya A, Rahman M, Zaman K, Banu J. Effects of n-3 fatty acids on autoimmunity and osteoporosis. Front Biosci. 2008; 13:4015-4020.

123. Weiler HA. Dietary supplementation of arachidonic acid is associated with higher whole body weight and bone mineral density in growing pigs. Pediatr Res. 2000;47(5):692-697.

124. Weiler HA, Fitzpatrick-Wong SC. Modulation of essential (n-6):(n-3) fatty acid ratios alters fatty acid status but not bone mass in piglets J Nutr. 2002;132(9):2667-2672.

125. Shen CL, Yeh JK, Rasty J, et al. Improvement of bone quality in gonad-intact middle-aged male rats by long-chain $\mathrm{n}-3$ polyunsaturated fatty acid. Calcif Tissue Int. 2007;80(4):286-293.

126. Hogstrom M, Nordstrom P, Nordstrom A. n-3 Fatty acids are positively associated with peak bone mineral density and bone accrual in healthy men: the NO2 Study. Am J Clin Nutr. 2007;85(3):803-807.

127. Banu J, Bhattacharya A, Rahman M, O'Shea M, Fernandes G. Effects of conjugated linoleic acid and exercise on bone mass in young male Balb/C mice. Lipids Health Dis. 2006;5:7.

128. Soung DY, Devareddy L, Khalil DA, et al. Soy affects trabecular microarchitecture and favorably alters select bone-specific gene expressions in a male rat model of osteoporosis. Calcif Tissue Int. 2006;78(6):385-391.

129. Banu J, Varela E, Fernandes G. Alternative therapies for the prevention and treatment of osteoporosis. Nutr Rev. 2012;70(1):22-40.

130. Chai SC, Hooshmand S, Saadat RL, Payton ME, Brummel-Smith K, Arjmandi BH. Daily apple versus dried plum: impact on cardiovascular disease risk factors in postmenopausal women. J Acad Nutr Diet. 2012;112(8):1158-1168

131. Hooshmand S, Chai SC, Saadat RL, Payton ME, Brummel-Smith K, Arjmandi BH. Comparative effects of dried plum and dried apple on bone in postmenopausal women. Br J Nutr. 2011;106(6): 923-930.

132. Kondo KL. Osteoporotic vertebral compression fractures and vertebral augmentation. Semin Intervent Radiol. 2008;25(4):413-424.

133. Levine JP. Pharmacologic and nonpharmacologic management of osteoporosis. Clin Cornerstone. 2006;8(1):40-53.

134. Schwarz P, Jorgensen NR, Mosekilde L, Vestergaard P. The evidence for efficacy of osteoporosis treatment in men with primary osteoporosis: a systematic review and meta-analysis of antiresorptive and anabolic treatment in men. J Osteoporos. 2011;2011:259818. 


\section{Publish your work in this journal}

Drug Design, Development and Therapy is an international, peerreviewed open-access journal that spans the spectrum of drug design and development through to clinical applications. Clinical outcomes, patient safety, and programs for the development and effective, safe, and sustained use of medicines are a feature of the journal, which

has also been accepted for indexing on PubMed Central. The manuscript management system is completely online and includes a very quick and fair peer-review system, which is all easy to use. Visit http://www.dovepress.com/testimonials.php to read real quotes from published authors.

Submit your manuscript here: http://www.dovepress.com/drug-design-development-and-therapy-journal 